\title{
Student Loan Burden, Financial Literacy, and Financial Behavior- Evidence From the 2018 FINRA Survey
}

\author{
Qian Li \\ Midwestern State University
}

In this paper I study the association between student loan and financial literacy level among households using the National Financial Capability Study (NFCS) data. Results show that respondents with student loans have lower financial knowledge scores compared to respondents that do not have student loans. In addition, both univariate tests and logit regression results show that higher level of financial literacy is related to lower likelihood of taking student loans, and lower likelihood of being late on making student loan payments. These findings suggest that improving financial literacy can potentially help families to make more reasonable student loan decisions.

Keywords: financial literacy, student loan, household finance

\section{INTRODUCTION}

Student loan is a very important means to fund education in the United States, and student loan debt has risen drastically in the past decades. According to the 2018 Report on the Economic Well-Being of U.S. Households published by Board of Governors of the Federal Reserve System, student loans are by far the most common form among the many forms of debt that finance education, held by 93 percent of those with their own education debt outstanding. The typical amount of education debt in 2018 among those with any outstanding was between $\$ 20,000$ and $\$ 24,999$.

The student loan burden can affect the financial and overall well-being in American households. Although not all researchers agree that the magnitude of student loan is worthy worrying, numerous researches have documented the impact of student loan burden on different personal and household financial decisions such as stock market participation and home ownership, as well as on individual's mental state and well-being.

It is been documented that higher level of financial literacy can help individuals and households make better financial decisions and improve their financial well-being. However, there is no existing literature about the relationship between student loan burden and financial literacy level. If higher financial literacy can help to prevent the overuse and abuse of student loans, one may expect to see the negative relationship between financial literacy level and the use of student loans or the rate of student loan defaults.

In this paper, I use the survey data from the 2018 wave of the National Financial Capability Study (NFCS) to examine the association between student loan and financial literacy among households. Both the univariate results and multivariate regression results after controlling for other variables such as gender and household income suggest that higher financial literacy level contributes to lower use of student loan and less frequent late payment of student loans. However, the same results do not hold for the relationship 
between student loan use and financial education requirement, suggesting a gap between required financial education and actual improvement in financial knowledge and financial decision making.

This paper contributes to the literature in that it is the first effort, in my knowledge, to examine the link between financial literacy and student loan behavior. The results can shed some lights on how to use financial education as a tool to effectively reduce the student loan burden and improve financial health for the households in the United States.

The rest of this paper is organized as the following: literature review is presented in the next section, followed by the introduction of data and sample as well as major variables examined in this study. Empirical test results, including results from the univariate tests and a set of logit regressions are then provided and discussed. The last section briefly concludes the article.

\section{LITERATURE REVIEW}

There is a consensus that higher education helps young people obtain better job prospects and higher income potential (Cho, Xu and Kiss, 2015), but cost for post-secondary education has also increased tremendously in the past decades (Lochner and, 2016). Both the high return and high cost of higher education together have increased the demand for student loans in the United States. Student loan can help to fund the education attainment, especially for those whose parents cannot or do not contribute to their education (Brown, Scholz and Seshadri, 2012). As a result, data from numerous sources, such as the Survey of Household Economics and Decision-making (SHED) and Survey of Consumer Finance (SCF), have shown that both the percentage of students takings student loans and the amount of student loan balances have risen significantly (see, for example, Akers and Chingos (2014) and Lochner and Monge-Naranjo (2016)).

With the rise of student loan use, both the public and the academia get concerned about whether students are borrowing too much and the student loan delinquency. Official data maintained by the Department of Education show a decline of Federal Student Loan Default rate after the 1990s but has started to rise after the 2007-2008 financial crisis (Lochner and Monge-Naranjo, 2015). A 2019 Bloomberg Businessweek article stated that "this generation of borrowers is chipping away at their (student loan) debt so slowly and some may not escape it until they are dead" (Bloomberg Businessweek, Aug 16, 2019). On the other hand, some believe that the fast pace of student loan growth is not worth worrying. Akers and Chingos (2014) argued that the increase in student debt can be largely attributed to Americans getting more education, especially graduate degrees, and there was no evidence of widespread financial hardship due to the student loans. They claimed that higher earnings after college, falling interest rates, and extended amortization periods for federal student loans all have contributed to alleviate the repayment burden from increasing student loans.

The student loan burden can affect household financial decision making and the overall well-being. For example, Elliott and Nam (2013) found that median net worth for households with outstanding student loan debt is nearly one third of the median net worth for households with no outstanding student loan debt in 2009 , and that households with outstanding student loan debt incur a loss of about 54 percent of net worth two years later compared with households with similar net worth levels but no student loan debt over the same period. There findings suggested that student loan debt may jeopardize the short-term financial health of U.S. households. Results from Archuleta, Dale and Spann (2013) show that student loans are associated with financial anxiety among their sample college students. Houle and Berger (2015) provided empirical evidence for a negative relationship between student loan debt and home ownership, although they argued that this relationship is substantively modest while statistically significant. Henager and Wilmarth (2018) showed that while having a college degree was positively associated with financial wellness, having student loans was negatively related to financial wellness. Kim and Chatterjee (2019) reported that student loan debt was related with lower (self-reported) life satisfaction and psychological well-being of their survey respondents.

The student loan issues being a crisis or not, improving the financial literacy level may be helpful to lighten the student debt burden and consequently improve the overall well-being of American households. 
Financial literacy and education have been documented to have impact on people's financial decisions. For example, Lusardi and Tufano (2015) studied relationship between financial literacy and debt loads. They found less financially knowledgeable individuals were more likely to report that their debt loads were excessive or that they are unable to judge their debt position. In addition, they found that individuals with lower levels of debt literacy were more likely to use high-cost borrowing and incur higher fees. Chatterjee, Fan, Jacobs and Hass (2017) studied the association among financial literacy, risk tolerance and goalsbased saving behavior such as saving for emergency, retirement or child education. They found that financial literacy is significantly and positively associated with having emergency funds and retirement planning among households. van Rooji, Lusardi and Alessie (2011) found that their survey respondents with lower level of financial literacy were much less likely to invest in the stock markets. Korankye and Guillemette (2000) also provided evidence that student debt negatively affected the probability of household owning stocks in non-retirement accounts.

Many financial literacy literatures focus on the financial literacy level among certain demographic groups, such as women, minority or young people. Among them, de Bassa Scheresberg (2013) found that most young adults lack basic financial knowledge, especially among women, minorities, and lower-income or less-educated people in this age group. Results in de Bassa Scheresberg (2013) also showed that higher financial literacy among young adults was associated with better financial outcomes such as less use of high-cost borrowing and more saving. Mottola (2013) reported that women were more likely to engage in costly credit card behaviors such as incurring late and over-the-limit fees than men, however the genderbased differences in credit card management seemed to disappear after controlling for financial literacy variables.

While financial literacy is documented to have impact on personal and household financial decisions, to my knowledge, there is no existing studies that examine the direct relationship between financial literacy level and student loan decisions. Such relationship can potentially shed some light on how more reasonable student loan decisions can be made by students and families, and how policymakers can incorporate financial education in programs designed to improve student loan affordability and lower the student loan delinquency. Therefore, the purpose of this study is to investigate the association between different measures of financial literacy level and student loan decisions, and discuss how financial education can potentially improve financial decision making related to student loans.

\section{DATA AND SAMPLE DESCRIPTION}

Data used in this paper is from the 2018 wave of the National Financial Capability Study (NFCS), a project funded by the Financial Industry Regulatory Authority (FINRA) Investor Education Foundation to $b$ enchmark key indicators of financial capability and evaluate how these indicators vary with underlying demographic, behavioral, attitudinal and financial literacy characteristics. The FINRA Foundation started conducting the NFCS survey in 2009 and has completed four waves: 2009, 2012, 2015 and 2018. The 2018 NFCS State-by-State Survey was conducted online from June through October 2018 among a nationally representative sample of over 27,000 American Adults. The survey contains over 130 questions in five general sections, including a demographic section that covers information such as gender, age, household income, education level, marital status and dependents. The demographic section is followed by questions that address four key areas of financial capability-making ends meet, planning ahead, managing financial products, and financial knowledge and decision-making. Details about the survey questions and data can be downloaded at https://www.usfinancialcapability.org/downloads.php.

Table lin the next page presents the descriptive statistics for the demographic of the overall sample. Since this research focuses on the use of student loans, respondents that answered either "don't know" or "prefer not to say" to the question "do you currently have student loans" are removed from the sample. To summarize, among the 26623 respondents that provided definitive answers to the question "do you currently have student loans", $56 \%$ are female and $44 \%$ are male. Around $10 \%$ of them are in the age group of $18-24$ years old and about $20 \%$ are over $65.53 .6 \%$ of them are married, and nearly $30 \%$ are single. About $35 \%$ have completed undergraduate education or higher (31.94\% have a bachelor's degree and $13.12 \%$ have a 
postgraduate degree), nearly $40 \%$ are employed full time while $22.87 \%$ are retired. Nearly $75 \%$ of the respondents are white/Caucasian, followed by $9.64 \%$ of African Americans, approximately $8 \%$ Hispanic, and $4.54 \%$ are Asian. The sample seems evenly distributed across different household income levels, while the largest income group (19.5\%) is between $\$ 50 \mathrm{k}$ and $\$ 75 \mathrm{k}$.

TABLE 1 (PANEL A) DESCRIPTIVE STATISTICS FOR THE OVERALL SAMPLE

\begin{tabular}{|c|c|c|}
\hline Gender & $\mathrm{N}$. & $\%$ \\
\hline Male & 11711 & 43.99 \\
\hline Female & 14912 & 56.01 \\
\hline \multicolumn{3}{|l|}{ Age Group } \\
\hline $18-24$ & 2675 & 10.05 \\
\hline $25-34$ & 4535 & 17.03 \\
\hline $35-44$ & 4434 & 16.65 \\
\hline $45-54$ & 4609 & 17.31 \\
\hline $55-64$ & 4879 & 18.33 \\
\hline $65+$ & 5491 & 20.63 \\
\hline \multicolumn{3}{|l|}{ Household Income } \\
\hline Less than $15 \mathrm{k}$ & 2928 & 11.00 \\
\hline At least $15 \mathrm{k}$ but less than $25 \mathrm{k}$ & 2739 & 10.29 \\
\hline At least $25 \mathrm{k}$ but less than $35 \mathrm{k}$ & 2886 & 10.84 \\
\hline At least $35 \mathrm{k}$ but less than $50 \mathrm{k}$ & 3851 & 14.46 \\
\hline At least $50 \mathrm{k}$ but less than $75 \mathrm{k}$ & 5195 & 19.51 \\
\hline At least $75 \mathrm{k}$ but less than $100 \mathrm{k}$ & 3791 & 14.24 \\
\hline At least $100 \mathrm{k}$ but less than $150 \mathrm{k}$ & 3408 & 12.80 \\
\hline$\$ 150 \mathrm{k}$ or more & 1825 & 6.85 \\
\hline \multicolumn{3}{|l|}{ Marital Status } \\
\hline Married & 14274 & 53.62 \\
\hline Single & 7816 & 29.36 \\
\hline Separated & 385 & 1.45 \\
\hline Divorced & 2965 & 11.14 \\
\hline Widowed/Widower & 1183 & 4.44 \\
\hline \multicolumn{3}{|l|}{ Education } \\
\hline Did not complete High School & 668 & 2.51 \\
\hline High School & 4777 & 17.94 \\
\hline GED & 1863 & 7.00 \\
\hline Some College & 7159 & 26.89 \\
\hline Associate & 2817 & 10.58 \\
\hline Bachelor & 5840 & 21.94 \\
\hline Post Graduate & 3499 & 13.14 \\
\hline \multicolumn{3}{|l|}{ Ethnicity } \\
\hline White or Caucasian & 19816 & 74.43 \\
\hline Black or African American & 2566 & 9.64 \\
\hline Hispanic or Latino/a & 2135 & 8.02 \\
\hline Asian & 1210 & 4.54 \\
\hline American Indian or Alaska Native & 502 & 1.89 \\
\hline Native Hawaiian or other Pacific Islander & 157 & 0.59 \\
\hline Other & 237 & 0.89 \\
\hline
\end{tabular}


The following survey questions from the section of "Managing Financial Products" are directly related to the use of student loans:

1. Do you currently have any student loans? If so, for whose education was this/were these loan(s) taken out?

2. How many times have you been late with a student loan payment in the past 12 months?

3. Before you got your most recent student loan, did you try to figure out how much your monthly payments would be?

4. Are you concerned that you might not be able to pay off your student loans?

5. Do you wish you had chosen to go to a less expensive college?

Panel B of Table 1 shows the number and percentage of household answering "yes" or "no" to the first student loan question. 6,949 out of 26,623 (26.1\%) respondents reveal that they have student loans. Among the households that do have student loans, $72.2 \%$ claim that the student loans were taken for their own education, while $25.92 \%$ have student loan from the spouse. About $14.35 \%$ claim to have student loan for their child(ren)'s education. Among the group of respondents that have student loans, these percent values add up to more than 1, since it's possible for someone to answer yes to more than one of the "for whose education" questions.

\section{TABLE 1 (PANEL B) PERCENTAGE OF HOUSEHOLDS CLAIMING TO CARRY STUDENT LOANS}

\begin{tabular}{|l|l|l|}
\hline Student Loan Status & N. & $\%$ \\
\hline Do not Have Student Loan & 19674 & 73.90 \\
\hline Have Student Loan & 6949 & 26.10 \\
\hline For Self & 5017 & 72.20 \\
\hline For Spouse & 1801 & 25.92 \\
\hline For Children & 997 & 14.35 \\
\hline For Grandchildren & 56 & 0.81 \\
\hline For "other person" (unspecified) & 63 & 0.91 \\
\hline
\end{tabular}

Table 2 presents some evidence about the difference in student loan use pattern among different demographic groups. $27.07 \%$ of the female respondents have student loan versus the $24.87 \%$ in male. Chisquare test results show that this difference in student loan use between the female and male groups is significant at $1 \%$ level. $35.9 \%$ of the minorities, including African American, Hispanic, Asian and others combined, carry student loans, which is significantly higher than the $22.73 \%$ among the white/Caucasian respondents. These results that overall female and minorities are more likely to have student loans are also consistent with the findings in student loan literature.

TABLE 2 STUDENT LOAN STATUS ACROSS DIFFERENT DEMOGRAPHIC GROUPS

\begin{tabular}{|c|l|l|l|l|c|}
\hline \multirow{2}{*}{$\begin{array}{c}\text { Have } \\
\text { Student Loan? }\end{array}$} & \multicolumn{2}{|c|}{ By Gender } & \multicolumn{2}{c|}{ By Ethnicity } & \multirow{2}{*}{ Total } \\
\cline { 2 - 5 } No & Male & Female & Non-white & White & 19674 \\
\hline & 8798 & 10876 & 4363 & 15311 & $77.27 \%$ \\
\hline Yes & $75.13 \%$ & $72.93 \%$ & $64.1 \%$ & 4505 & 6949 \\
\hline Total & 2913 & 4036 & 2444 & $22.73 \%$ & \\
\hline Chi-Square & $24.87 \%$ & $27.07 \%$ & $35.9 \%$ & 19816 & 26623 \\
\hline P-value & 11711 & 14912 & 6807 & \multicolumn{2}{c|}{$\begin{array}{c}455.606 \\
(<0.0001)\end{array}$} \\
\hline
\end{tabular}


Table 3 presents some summaries on student loan-related questions among respondents who claim to have student loans. More than half of the respondents (53.13\%) acknowledge that they did not try to figure out how much the monthly payment would be before they took out the student loan. At least $29 \%$ of the respondents have been late with student loan payments for at least once. In addition, nearly half (48.14\%) of the respondents are concerned about not being able to pay off their student loans. $39.81 \%$ of the respondents wish they had chosen a less expensive college. These results are a starting point for us to understand the impact of student loan on household financial health and overall wellbeing.

TABLE 3

\section{SUMMARY OF RESPONSES TO STUDENT LOAN RELATED QUESTIONS}

\begin{tabular}{|l|l|l|}
\hline $\begin{array}{l}\text { Tried to Figure Out How Much the Payment Would Be } \\
\text { Before Getting the Last Student Loan }\end{array}$ & $\begin{array}{l}\text { Number of } \\
\text { Observation }\end{array}$ & $\%$ \\
\hline Yes & 2839 & 40.85 \\
\hline No & 3692 & 53.13 \\
\hline Don't know & 377 & 5.43 \\
\hline Prefer not to say & 41 & 0.59 \\
\hline Been Late with Student Loan Payments & & 26.06 \\
\hline Never: No Payment Due & 1811 & 37.34 \\
\hline Never: Always Pay on time & 2595 & 9.93 \\
\hline Once & 690 & 19.13 \\
\hline More than Once & 1329 & 5.96 \\
\hline Don't know & 414 & 1.58 \\
\hline Prefer not to say & 110 & \\
\hline Concerned about Not Able to Pay Off Student Loan & & 48.14 \\
\hline Yes & 3345 & 46.15 \\
\hline No & 3207 & 5.07 \\
\hline Don't know & 352 & 0.65 \\
\hline Prefer not to say & 45 & \\
\hline Wish Had Chosen Less Expensive College & & 39.81 \\
\hline Yes & 2359 & 51.60 \\
\hline No & 3058 & 7.76 \\
\hline Don't know & 460 & 0.83 \\
\hline Prefer not to say & 49 & \\
\hline
\end{tabular}

Table 4 presents some evidence on potential impact from carrying student loan on household financial decisions. As shown in Table 4, 40.24\% of the respondents that have student loans have emergency fund, comparing to the $56.27 \%$ from respondents that do not have student loans. Similarly, respondents that have student loans are less likely to have a saving account, have investments, or own a house. $76.62 \%$ of the respondents that have student loans claim to have a saving account, money-market account or CD, comparing to $74.64 \%$ from the respondents with student loans. $38.57 \%$ of the respondents that have student loans claim to have investments in stocks, bonds, mutual funds, or other securities, not including the retirement accounts. This is higher than the $32.14 \%$ from respondents with student loans. $66.48 \%$ of the respondents that have student loans currently own their homes, comparing to the $50.2 \%$ from the respondents with student loans. These results are generally consistent with literature on the impact of student loan on household financial decision and financial status. 
TABLE 4

STUDENT LOAN STATUS VS. FINANCIAL DECISIONS/BEHAVIOR

\begin{tabular}{|c|c|c|c|c|c|c|c|c|}
\hline & \multicolumn{2}{|c|}{$\begin{array}{l}\text { Have Emergency } \\
\text { Fund }\end{array}$} & \multicolumn{2}{|c|}{$\begin{array}{l}\text { Have Saving } \\
\text { Account }\end{array}$} & \multicolumn{2}{|c|}{ Have Investments } & \multicolumn{2}{|c|}{ Home Ownership } \\
\hline & Yes & No & Yes & No & Yes & No & Yes & No \\
\hline \multirow{2}{*}{$\begin{array}{l}\text { Do not } \\
\text { have SL }\end{array}$} & 10595 & 8235 & 14718 & 4490 & 6833 & 10884 & 12922 & 6515 \\
\hline & $56.27 \%$ & $43.73 \%$ & $76.62 \%$ & $23.38 \%$ & $38.57 \%$ & $61.43 \%$ & $66.48 \%$ & $33.52 \%$ \\
\hline \multirow{2}{*}{ Have SL } & 2701 & 4011 & 5075 & 1724 & 2012 & 4248 & 3440 & 3413 \\
\hline & $40.24 \%$ & $59.76 \%$ & $74.64 \%$ & $25.36 \%$ & $32.14 \%$ & $67.86 \%$ & $50.2 \%$ & $49.8 \%$ \\
\hline $\begin{array}{l}\text { Chi- } \\
\text { Square } \\
\text { (P-value) }\end{array}$ & \multicolumn{2}{|c|}{$\begin{array}{l}509.156 \\
(<.0001)\end{array}$} & \multicolumn{2}{|c|}{$\begin{array}{l}10.8368 \\
(0.001)\end{array}$} & \multicolumn{2}{|c|}{$\begin{array}{c}82.067 \\
(<.0001)\end{array}$} & \multicolumn{2}{|c|}{$\begin{array}{l}571.675 \\
(<.0001)\end{array}$} \\
\hline
\end{tabular}

The NCFS survey also asks questions about the respondents' financial knowledge, including the objective financial knowledge level (how much they think they know) and questions that can review subjective financial knowledge level (how much they actually know). As to the objective financial knowledge level, respondents are asked "One a scale from 1 to 7 , where 1 means very low and 7 means very high, how would you access your overall financial knowledge", and, on the same scale, "overall, how would you rate the quality of the financial education you received".

In addition, the 2018 survey uses six questions to measure a respondent's objective financial knowledge level. The rational of using these kinds of questions in a survey to measure financial literacy are explained in Lusardi and Mitchell (2014). These questions include:

1. Suppose you had $\$ 100$ in a savings account and the interest rate was $2 \%$ per year. After 5 years, how much do you think you would have in the account if you left the money to grow?

2. Imagine that the interest rate on your savings account was $1 \%$ per year and inflation was $2 \%$ per year. After 1 year, how much would you be able to buy with the money in this account?

3. If interest rates rise, what will typically happen to bond prices?

4. Suppose you owe $\$ 1,000$ on a loan and the interest rate you are charged is $20 \%$ per year compounded annually. If you didn't pay anything off, at this interest rate, how many years would it take for the amount you owe to double?

5. True or False: A 15-year mortgage typically requires higher monthly payments than a 30-year mortgage, but the total interest paid over the life of the loan will be less.

6. True or False: Buying a single company's stock usually provides a safer return than a stock mutual fund

The total number of questions that a respondent answers correctly is used to measure the respondent subjective financial knowledge or financial literacy level. Therefore, the lowest possible value of this variable would be 0 and the highest possible value would be 6 . Table 5 shows the descriptive statistics for financial literacy measures, including the objective financial knowledge score, the self-assessed financial knowledge, and self-assessed quality of financial education received. On average respondents rank their own financial knowledge as 5.14 out of 7 , and the quality of financial education they received as $5.35 \%$ out of 7, while they score 3.15 out of 6 in the subjective financial knowledge questions. The median values of both the self-assessed financial knowledge rating and the self-assessed quality of financial education received are 5 out of 7, comparing to the median value of 3 out of 6 in the objective financial knowledge score. It should not be surprising that people tend to think they know more than what they actually do know. It's worth pointing out that in Table 5 , since only about $15 \%$ of the respondent reported that they were required to take financial education, number of respondents that tried to rank the quality of the financial education they have received (5404 observations) is much smaller than the overall sample presented in Table 5 . 


\section{TABLE 5}

\section{DESCRIPTIVE STATISTICS ON OBJECTIVE AND SUBJECTIVE FINANCIAL KNOWLEDGE MEASURE}

\begin{tabular}{|l|c|c|c|c|c|c|}
\hline & N & Mean & Median & Std Dev & Min & Max \\
\hline $\begin{array}{l}\text { Objective Financial Knowledge Score } \\
\text { (score from 0 to 6) }\end{array}$ & 26623 & 3.15 & 3 & 1.68 & 0 & 6 \\
\hline $\begin{array}{l}\text { Self-Assessed Financial Knowledge } \\
\text { Rating (rating from 1 to 7) }\end{array}$ & 25992 & 5.14 & 5 & 1.34 & 1 & 7 \\
\hline $\begin{array}{l}\text { Self-assessed Quality of Financial } \\
\text { Education Received (rating from 1 to 7) }\end{array}$ & $5404^{*}$ & 5.35 & 5 & 1.42 & 1 & 7 \\
\hline
\end{tabular}

\section{TESTS AND RESULT DISCUSSIONS}

\section{Univariate Tests}

To understand the effect of financial education requirement and financial literacy on student loan uses, we first divide the sample into two groups according to whether (they claimed) they were required to have financial education. As shown in Table 6, among all respondents that were required to take financial education, $44.47 \%$ have student loans, higher than the $22.56 \%$ among respondents who were not required to take financial education, suggesting that financial education requirement does not necessary stop people from obtaining student loans. Financial education does seem to prompt people to try to do some research and calculation and figure out how much they need to pay back each month before signing up for any student loan. Among respondents who were required to take financial education, $60.88 \%$ of them did try to figure this out, comparing to only $37.17 \%$ among those who were not required to take financial education. However, the group of respondents that had required financial education did not show advantage of avoiding late payments, nor were they less concerned about being able to pay off the student loans. Overall the data did not show much support about the assumed benefit of requiring financial education on student loan uses. This may imply a gap between the financial education requirements and the quality of the financial education provided or the actual improvement of financial literacy.

TABLE 6

\section{REQUIRED FINANCIAL EDUCATION VS. STUDENT LOAN USES}

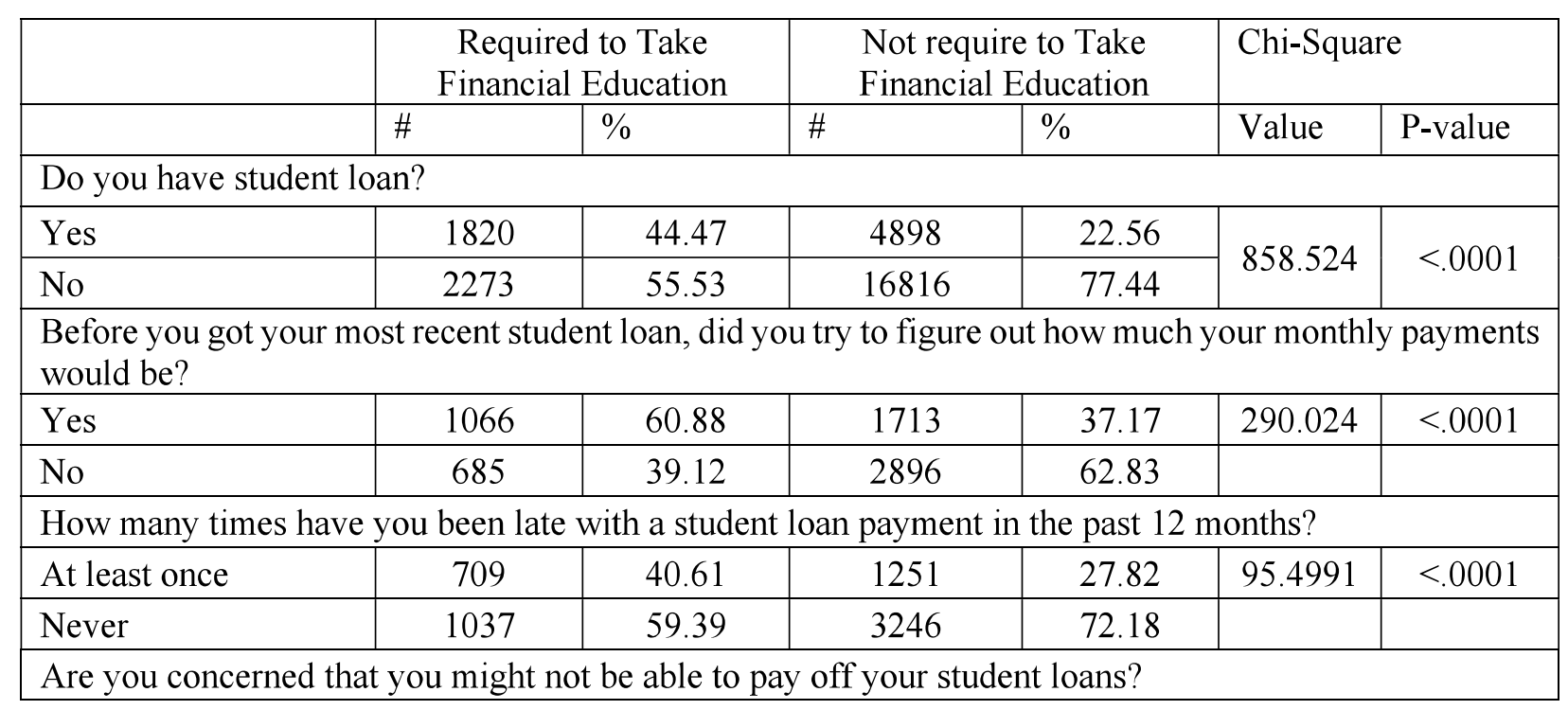




\begin{tabular}{|l|c|c|c|c|c|c|}
\hline Yes & 1115 & 63.21 & 2142 & 46.31 & 31.3843 & $<.0001$ \\
\hline No & 649 & 36.79 & 2483 & 53.69 & & \\
\hline Do you wish you had chosen to go to a less expensive college? \\
\hline Yes & 985 & 30.84 & 2104 & 14.97 & 446.083 & $<.0001$ \\
\hline No & 2209 & 69.16 & 11954 & 85.03 & & \\
\hline
\end{tabular}

We then divide the sample into two groups, the high financial literacy group and the low financial literacy group, based on their financial literacy scores. High financial literacy is defined as having the financial literacy score higher than or equal to 4 (out of 7). This treatment is consistent with the method used in financial literacy literature such as Mottola (2013). As shown in Table 7, within the higher financial literacy group, $21.49 \%$ of the respondents carry student loan, comparing to the $29.71 \%$ within the group with lower financial literacy scores. The group with higher financial literacy level is also less likely to be late in making student loan payment, as $79.27 \%$ of them has never been late, comparing to the $62.25 \%$ in the lower financial literacy group. In addition, respondents in the high financial literacy group are less concerned about not being about to pay off their student loans, and fewer of them wished they had chosen a less expensive college. Overall, the survey data suggest that higher level of financial literacy is associated with less use student loan, more responsible or less costly behavior after taking on the student loan, and maybe consequently, are more likely to benefit from taking student loan which help them to fund the education that they don't regret for. However, less intuitively, a higher percent of the respondents in the high financial literacy group did not try to figure out the amount of monthly student loan payment before taking on the student loan. This may reflect the limitation of what the popular financial literacy score tends to measure-it focuses more on the "knowledge" or "skills", and less on the "habit" or "prudence". On the other hand, it may also suggest the importance of teaching the habit or prudence in an effective financial education program.

TABLE 7

FINANCIAL LITERACY LEVEL VS. STUDENT LOAN USES

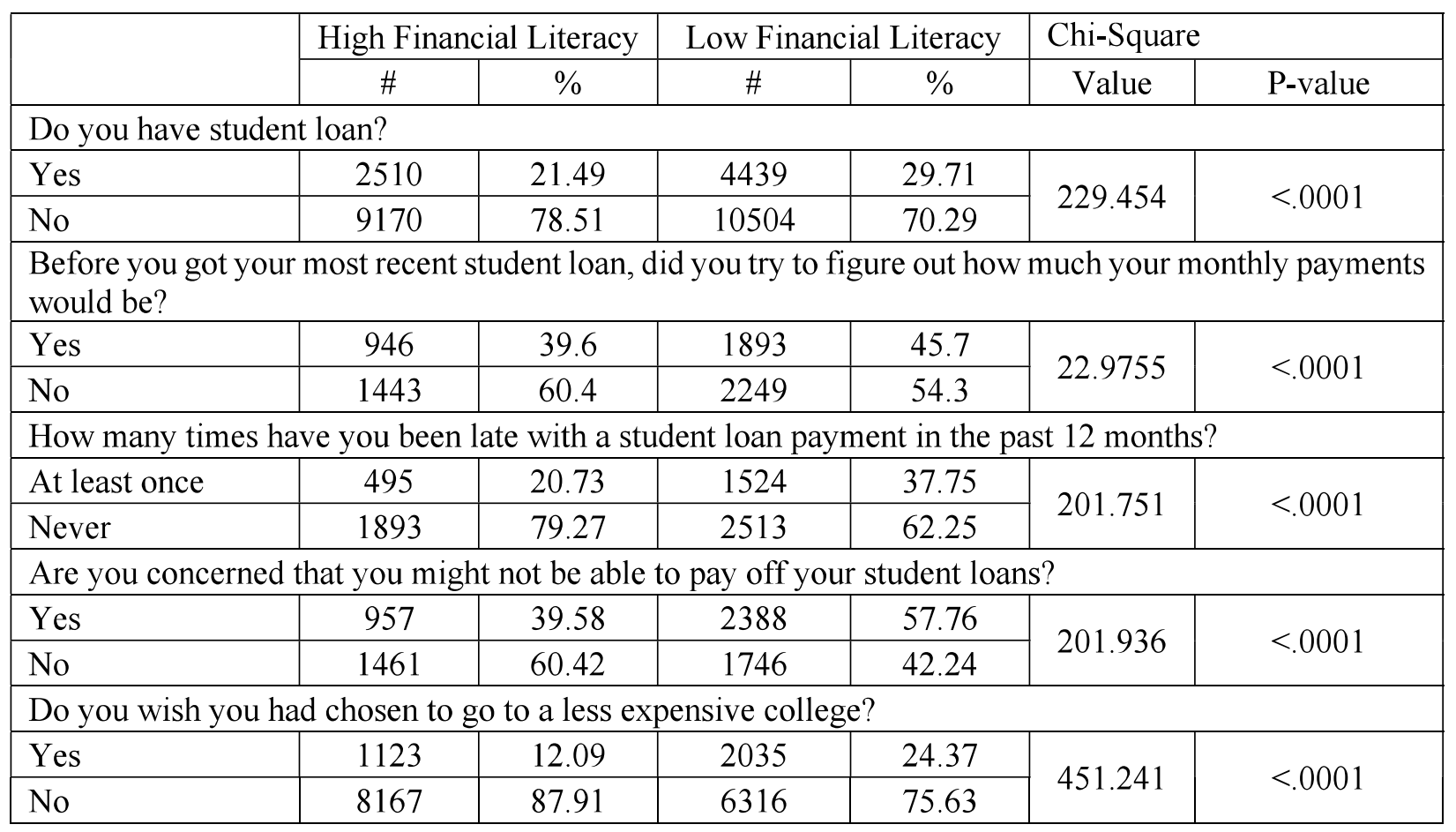


If we look at group of households that have student loan versus the group of households that do not carry student loans, their financial literacy level show significant differences, as reported in Table 8 . Between the two groups, we compare their objective financial literacy score, their self-assessed financial knowledge level, and their self-rated quality of financial education received. By all three measures, the group of respondents that carry student loans show lower level of financial knowledge, subjective or objective.

TABLE 8

DIFFERENCE IN FINANCIAL LITERACY LEVEL BETWEEN STUDENT LOAN GROUPS

\begin{tabular}{|c|c|c|c|c|c|}
\hline & & Do Not Have SL & Have SL & t Value & $\operatorname{Pr}>|t|$ \\
\hline \multirow{4}{*}{$\begin{array}{l}\text { Objective Financial } \\
\text { Literacy Score }\end{array}$} & $\mathrm{N}$ & 19674 & 6949 & \multirow{4}{*}{14.77} & \multirow{4}{*}{$<.0001$} \\
\hline & Mean & 3.2359 & 2.8916 & & \\
\hline & Median & 3 & 3 & & \\
\hline & Std Dev & 1.706 & 1.5645 & & \\
\hline \multirow{4}{*}{$\begin{array}{l}\text { Self-assessed } \\
\text { Financial } \\
\text { Knowledge Level }\end{array}$} & $\mathrm{N}$ & 19136 & 6856 & \multirow{4}{*}{10.48} & \multirow{4}{*}{$<.0001$} \\
\hline & Mean & 5.1886 & 4.9911 & & \\
\hline & Median & 5 & 5 & & \\
\hline & Std Dev & 1.3109 & 1.415 & & \\
\hline \multirow{4}{*}{$\begin{array}{l}\text { Self-rated Quality } \\
\text { of Financial } \\
\text { Education } \\
\text { Received }\end{array}$} & $\mathrm{N}$ & 3450 & 1954 & \multirow{4}{*}{5.11} & \multirow{4}{*}{$<.0001$} \\
\hline & Mean & 5.4278 & 5.2231 & & \\
\hline & Median & 6 & 5 & & \\
\hline & Std Dev & 1.3256 & 1.5633 & & \\
\hline
\end{tabular}

\section{Regression Results}

To examine the impact of financial literacy in the use of student loans, we use a set of logit regressions to test the following hypothesis:

\section{H1: Financial literacy level is negatively related to the likelihood of using student loans.}

H2: Financial literacy level is negatively related to the likelihood of being late on student loan payments.

H3: Financial literacy level is positively related to the likelihood of trying to figure out how much the monthly payment would be before taking on student loans.

The regression results are reported in Table 9. The main independent variable of interest is the (objective) Financial Literacy Score. Control variables include respondent's gender (variable Female takes value of 1 for female and 0 for male), ethnicity (variable White takes value of 1 for white/Caucasians and 0 otherwise), household income (variable Household Income takes value of 1 if the respondent reports a household income above $\$ 50,000$ per year, and zero if the household income is below $\$ 50,000$ ), marital status (variable Married takes value of 1 if the respondent is married, and zero if single, divorced, separated or widowed), and child status (variable Child takes value of one if the respondent claims to have at least one financial dependent child at home, and zero otherwise).

In the first regression, the dependent variables is Having Student Loan, which takes the value of 1 if the observation has student loan debt and 0 otherwise. The result shows that the financial literacy score is negatively associated with the likelihood of having student loan after controlling for other variables such as household income, gender, and ethnicity. The coefficient of -0.0788 indicates that if other variables are held constant, for one unit increase in the financial literacy score, the log odds of carrying student loan 
(versus not carrying student loan) decrease by 0.0788 . Converting the log odds to the exponentiated value, the odd ratio estimate shows that for one point increase in the financial literacy score, the odd ratio of carrying student loan versus not carrying student loans drops 0.924 times.

Similar results hold, while not presented here, when the binary variable of Child was replaced with the number of financially dependent children in the household, and the binary household income variable were replaced with a variable that takes value ranging from 1-7 based on the household income group. The negative sign and statistical significance for the coefficient estimate for the financial literacy score do not change in these robustness tests.

Within the group of respondents that do have student loans, the dependent variable in the second logit regression is Late Payment, which takes the value of 1 if the respondent has been late in making student loan repayments for at least once, and 0 if the respondent has never been late in paying student loans. The result shows that higher financial literacy score is negatively associated with the odds of being late in making student loan payment, after controlling for other variables. For one point increase in the financial literacy score, the log odds of being late on student loan payments (versus never being late in payments) decrease by 0.2277 . Converting the log odds to the exponentiated value, the odd ratio estimate shows that one point increase in the financial literacy score can potentially bring down the odds of being late on student loan payments versus never being late by 0.796 times.

The last regression uses the dependent variable Pre_Check, which takes value of 1 if the respondent tried to figure out the amount of monthly payment before deciding on getting the student loan, and zero if no such effort occurred before getting the student loan. Contrary to expected benefit of improving financial literacy, higher financial literacy score does not seem to be associated with higher likelihood of trying to figure out the monthly student loan payment obligation before taking on student loan loans. 


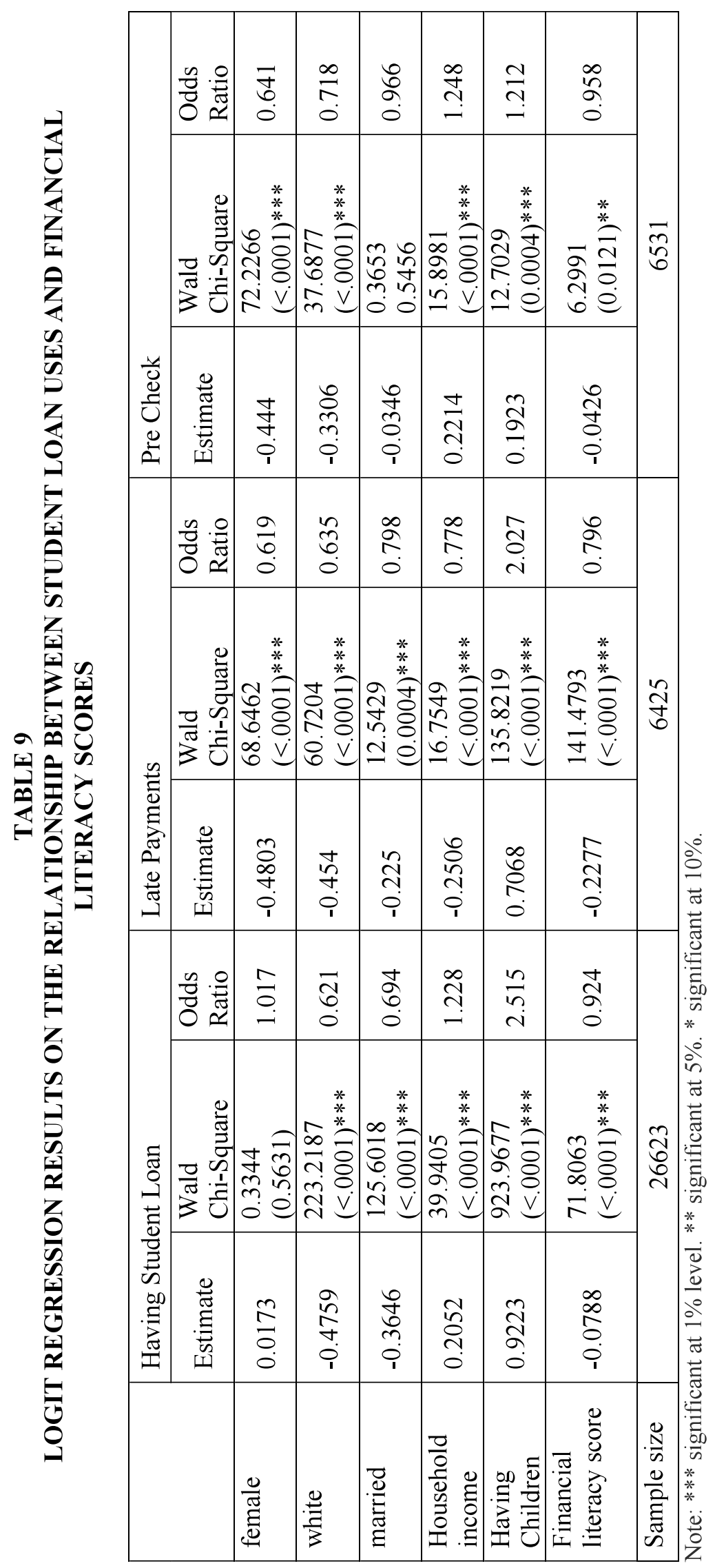

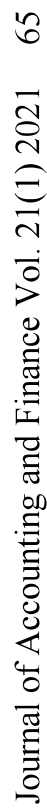


For each independent variable, the coefficient estimate represents the marginal log odds when other variables are held constant. Wald Chi-square test statistics and associated p-values (in parenthesis) are presented

\section{SECTION 5: SUMMARY AND DISCUSSION}

In this article I use the 2018 wave of the NFCS data to examine the use of student loan among American households and study the relationship between student loan and financial literacy level, and the impact of student loans on household financial decisions. Data used in this article confirmed with literature about the demographic difference in taking student loans, and the impact of student loan on household financial decisions. Moreover, I present some evidences that higher financial literacy level is associated with to lower use of student loan. In addition, higher financial literacy score is associated with less frequent late payment of student loans. However, there is no evidence that respondents with higher financial literacy scores do their due diligence and tried to figure out how much their monthly student loan payment would be before taking on the student loans. These results suggest that improving financial literacy can potentially help households to make more reasonable student loan decisions, but currently there may exist a gap between required financial education and actual improvement in financial knowledge and financial decision making.

Due to the limitation of the survey data, we cannot further quantify the impact of financial literacy on the size of the student loan, or the impact of the student loan size on household financial decisions. For example, while NFCS survey asks whether a respondent has student loan, there is no additional information such as the dollar amount of student loan balance carried. In addition, while the correlation between the financial literacy score and student loan use is documented here, actual causality between financial literacy and student loan uses can hardly be established using the NFCS survey data. Nevertheless, this article can be a starting point to understand the relationships between financial literacy and student loan uses, and the role of financial education in lightening the student debt burden in the United States.

\section{REFERENCES}

Akers, B., \& Chingos, M.M. (2014). Is a Student Loan Crisis on the Horizon? Brown Center on Education Policy at Brookings Report. Retrieved from https://www.brookings.edu/wpcontent/uploads/2016/06/Is-a-Student-Loan-Crisis-on-the-Horizon.pdf

Archuleta, K.L., Dale, A., \& Spann, S.M. (2013). College Students and Financial Distress: Exploring Debt, Financial Satisfaction, and Financial Anxiety. Journal of Financial Counseling and Planning, 24(2), 50-62.

Brown, M., Scholz, J.K., \& Seshadri, A. (2012). A New Test of Borrowing Constraints for Education. The Review of Economic Studies, 79(2), 511-538.

Chatterjee, S., Fan, L., Jacobs B., \& Haas, R. (2017). Risk Tolerance and Goals-Based Savings Behavior of Households: The Role of Financial Literacy. Journal of Personal Finance, 16(1), 66-77.

Cho, S.H., Xu, Y., \& Kiss, D.E. (2015). Understanding Student Loan Decisions: A Literature Review. Family \& Consumer Sciences, 43(3), 229-243.

de Bassa Scheresberg, C. (2013). Financial Literacy and Financial Behavior among Young Adults: Evidence and Implications. Numeracy, 6(2), Article 5.

Elliott, W., \& Nam, I.S. (2013). Is student debt jeopardizing the short-term financial health of U.S. households? Federal Reserve Bank of St. Louis Review, (September issue), 405-424.

Henager, R., \& Wilmarth, M. (2018). The Relationship Between Student Loan Debt and Financial Wellness. Family \& Consumer Sciences, 46(4), 381-395.

Houle, J., \& Berger, L. (2015). Is Student Loan Debt Discouraging Homeownership among Young Adults? Social Service Review, 89(4), 589-621.

Kim, J., \& Chatterjee, S. (2019). Student Loans, Health, and Life Satisfaction of US Households: Evidence from a Panel Study. Journal of Family and Economic Issues, 40(1), 36-50. 
Korankye, T., \& Guillemette, M. (2020). Student Debt and Stock-ownership Decisions of U.S. households. Applied Economics Letters, forthcoming.

Lochner, L., \& Monge-Naranjo, A. (2016). Student loans and repayment: Theory, evidence, and policy. Handbook of the Economics of Education (Volume 5, Chapter 8, pp. 397-478). Elsevier.

Lusardi, A., \& Mitchell, O. (2014). The Economic Importance of Financial Literacy: Theory and Evidence. Journal of Economic Literature, 52(1), 5-44.

Lusardi, A., \& Tufano, P. (2015). Debt literacy, financial experiences, and overindebtedness. Journal of Pension Economics and Finance, 14(4), 332-368.

Mottola, G. (2013). In Our Best Interest: Women, Financial Literacy, and Credit Card Behavior. Numeracy, 6(2), Article 2.

Nasiripour, S. (2019, August 16). At This Rate, It Will Take 100 Years to Pay Off America's Student Debt. Bloomberg Businessweek. Retrieved from https://www.bloomberg.com/news/articles/2019-08-16/you-may-be-dead-before-you-pay-offyour-student-loans

Report on the Economic Well-Being of U.S. Households in 2018. (2019, May). Retrieved from https://www.federalreserve.gov/publications/files/2018-report-economic-well-being-ushouseholds-201905.pdf

van Rooji, M., Lusardi A., \& Alessie, R. (2011). Financial literacy and stock market participation. Journal of Financial Economics, 101(2), 449-472.

Xiao, J., Tang, C., \& Shim, S. (2009). Acting for Happiness: Financial Behavior and Life Satisfaction of College Students. Social Indicators Research, 92(1), 53-68. 